\title{
Josef V. Polišenský, 1915-2001
}

Josef Polišenský, emeritus professor of world history at Charles University and nestor of Czech historians, died in Prague on 11 January 2001 at the age of eighty-five. Born on 16 December 1915 in Prostějov, Moravia, Polišenský enrolled at Charles University in Prague in 1934, majoring in the unusual combination of history and English. By 1939 he had completed most of his examinations as well as his doctoral dissertation, but he could not receive his Ph.D. until 1945. (In 1958, he was also awarded the new degree of Doctor of Historical Sciences, D.Sc.) During the war years, Polišenský taught English at gymnasia in Prague and Pilsen. In 1951 he was appointed docent and in 1957 professor of world history (v̌seobecné dĕjiny) at his alma mater. From 1948 to 1962 he was also an adjunct professor at Palacký University in Olomouc, Moravia.

One of the most eminent Czech historians of the twentieth century, Polišenský was also well known and highly honored abroad. During his long life, he witnessed the many political vicissitudes the Czechs have experienced since they emerged from the Habsburg monarchy. A prominent member of the so-called lost generation of Czech historians, his posthumous memoir, Historik v ménicím se svétě (2001), details the difficulty of maintaining one's personal and professional integrity in the Nazi Protectorate and in communist Czechoslovakia. Polišenský is largely credited with helping to turn Czech historiography from its traditionally narrow national focus toward broader European and world contexts and with keeping Czech historians at least minimally informed about western historiography and in touch with their western counterparts during the long period of communist isolation.

Polišenský joined the Czechoslovak Communist Party, but he was not a doctrinaire Marxist, and his many contacts with the west and his lively interest in western theories and methodologies of history exposed him repeatedly to charges of "positivism" and "liberalism" by party cadres, starting in 1958. Polišenský took advantage of the relaxed conditions of the 1960s to publish and work abroad more freely, but-by his own admission - he was only marginally involved with the Prague Spring. Nevertheless, in 1971 he was relieved of his teaching duties at the university and transferred to the Center for Ibero-American Studies, which he proceeded to develop into an outstanding European institution of its kind. He returned to Charles University after 1989. In his fifty-five years there, he helped train two generations of Czech historians. Foreign students and scholars from all over the world came to attend his English-language courses there and to consult with him privately. He himself taught at more than twenty universities in Europe and the Americas, including the University of California, Berkeley, in 1969.

Even by compulsive Czech standards, Polišenský was incredibly prolific. A preliminary tally of the works - scholarly, pedagogical, popular, journalistic - to which he contributed in some way from 1937 to 2000 totals about one thousand items, including more than sixty volumes that he authored or edited alone. He was proficient in all of the major European languages, and many of his publications appeared in foreign translations. They testify to Polišenskýs broad interest in multiple aspects of historical development and his use of a variety of historiographical techniques. Perhaps the most distinguishing characteristic of his scholarship is its thorough grounding in archival research. Himself a trained archivist, he had an unchallenged knowledge of the contents of his country's archives, especially those of the nobility, not to mention relevant materials in the archives and libraries of Europe and the Americas. In his Otázky studia obecných dëjin (2 vols., 1957 and 1963), he surveyed the holdings of Czech and Slovak archives for the study of world history.

Polišensky's research ranged from the sixteenth through the twentieth centuries and earned him worldwide recognition as an authority on early modern Europe, Comenius, and Ibero-America. Above all, he was preoccupied with "the European crisis of the seventeenth century" and the Thirty Years' War. His Trícetiletá válka a europské krize 17. století (1970) and the monumental documentary collection he organized and edited, Documenta 
Bohemica bellum tricennale illustrantia (7 vols., 1971-1981), brought him international acclaim. There and elsewhere, Polišenský exposed the intricate involvement of the English, French, Spanish, and Dutch in the rebellion of the Bohemian estates against the Habsburgs in 1618-1620 and its tragic aftermath, and he introduced a host of previously unused archival sources into the complicated nexus of historical issues and debates. He also maintained a lifelong interest in a major personality of the period, Comenius. The last in a continuous stream of Polišenskýs studies of his life and thought was Komenský, muż labyrintu a nadĕje (1996).

Polišenský was also seriously involved with three other major topics-the revolutionary changes in Europe in the first half of the nineteenth century and Anglo-American and Ibero-American history. To the first, he contributed two basic studies: Napoleon a srdce Evropy (1971) and Revoluce a kontrarevoluce v Rakousku 1848 (1975). He is rightly considered one of the pioneers of Czech study of the other two fields. He produced many survey histories of Great Britain, the United States, Spain, Portugal, and the countries of Latin America and more focused treatments of the historic ties between England and the Czech lands, Czech emigration to the United States, and Spanish and Portuguese expansion overseas.

A self-professed "workaholic," Polišenský-repeatedly hospitalized and almost totally blind in his last years-remained professionally active literally to his last day, drawing on his prodigious memory to dictate manuscripts and deliver oral presentations. His last foreign appearances were in Scotland in 1999 and in Texas and California in 2000. At the time of his death, a group of his American, British, and Czech colleagues were preparing to nominate him for an honorary foreign membership in the American Historical Association.

"Poli," as his friends called him, was a giant-a short, slight, gentle giant-insatiably passionate about history and unstintingly generous to those who sought his assistance. Cest jeho památce!

JOSEPH FREDERICK ZACEK State University of New York, Albany April 2001

\section{Jörg K. Hoensch, 1935-2001}

Jörg K. Hoensch's colleagues and friends were shocked by his sudden death on 24 February 2001 at the age of 65. Since 1972, Hoensch had held the chair in eastern European history at the University of the Saarland in Saarbrücken, and he had been a visiting professor in several institutions abroad, including Columbia University in 1976-1977.

Hoensch was born in Bruntál (Freudenthal) in Germanized northern Moravia on 8 September 1935. His father resettled the family in the American zone of Germany in 1947, where Hoensch completed his secondary education; he then studied in universities in Marburg/Lahn, Vienna, Bristol, and Tübingen. Hoensch received an M.A. from the University of California, Berkeley, in 1961, his Dr. Phil. at Tübingen in 1963, and his habilitation at Tübingen in 1972. His meticulous scholarship, command of foreign languages, and devotion to history won him assistantships at Tübingen with Dietrich Geyer and Werner Markert. After a brief docentship there, he was named to the chair in Saarbrücken. Since the 1960s, Jörg K. Hoensch has been recognized as one of the foremost historians of east central Europe and of Slovakia in particular. His many writings threw light on relatively unexplored chapters in the Slovak past and present.

Hoensch was elected a member of Collegium Carolinum in Munich and in 1995 joined the editorial board of its journal Bohemia. In 2000, he was elevated to coeditorship of Bohemia with Ferdinand Seibt and Hans Lemberg. On the occasion of his 65 th birthday in 2000, five colleagues at Collegium presented him with a Festgabe titled Studia Slovaca: Studien zur Geschichte der Slowaken und der Slowakei. It included twelve essays Hoensch had written from the 1960s to the 1990s and a bibliography of his publications: 15 mono- 